\title{
Hemlock Woolly Adelgid Adelges tsugae (Annand 1928) (Insecta: Hemiptera: Adelgidae) ${ }^{1}$
}

\author{
Jeremiah R. Foley, Scott Salom, and Carey Minteer ${ }^{2}$
}

\section{Introduction}

The hemlock woolly adelgid, Adelges tsugae (Annand) (Figure 1), is an invasive insect attacking eastern hemlock (Tsuga canadensis) (L.) Carrière and Carolina hemlock (Tsuga caroliniana) Engelmann in the eastern United States. Originally from Japan, the hemlock woolly adelgid was first detected in the eastern United States in Richmond, Virginia around the 1950s (Havill and Foottit 2007) and has since spread throughout the Appalachian Mountains and several counties in Michigan and Nova Scotia (Figure 2). This insect has been reported to spread at a rate of $15.6 \mathrm{~km} /$ year in the south, but it spreads more slowly $(8.1 \mathrm{~km} /$ year $)$ in the north, a reduction attributed to colder temperatures (Evans and Gregoire 2007). Once established, hemlock woolly adelgid is a serious threat to forest ecosystems and can kill its host within four years (McClure 2001). Hemlock woolly adelgid feeds by inserting its piercing-sucking mouth parts into plant tissues and extracting stored plant nutrients (Young and Shields 1995). Over the past half a century, considerable attempts have been made to thwart the impact and spread of hemlock woolly adelgid through efforts including silvicultural, chemical, and biological control.

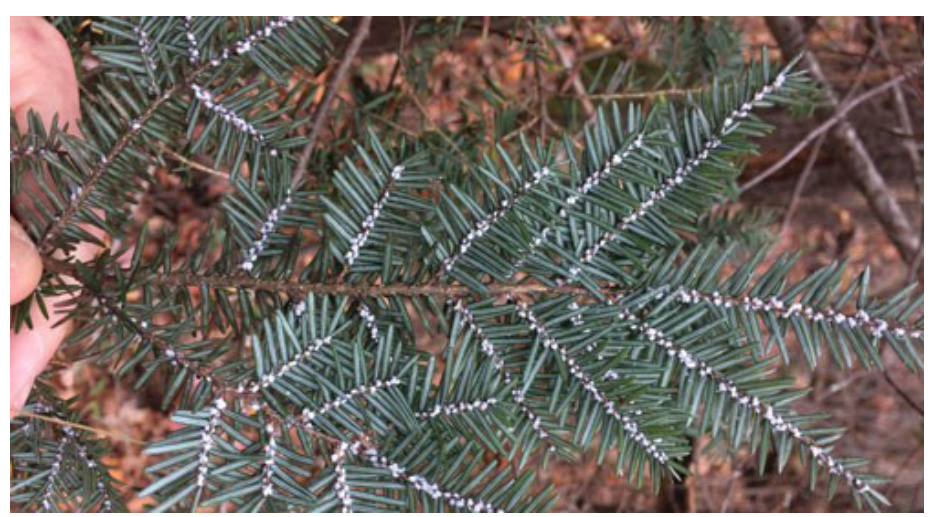

Figure 1. Flocculent (waxy woolly mass) of hemlock woolly adelgid Adelges tsugae (Annand).

Credits: Jeremiah R. Foley, Virginia Polytechnic Institute and State University

\section{Distribution}

Adelges spp. have a worldwide distribution within temperate environments and have been documented on all hemlock species (Havill and Foottit 2007). The hemlock woolly adelgid was first described in 1922 as Chermes funitectus Dreyfus from western Hemlock, Tsuga heterophylla (Sargent) in the northwestern continental United States (Chrystal and Story 1922). However, Annand (1928) and Carter (1971) believed that Chermes funitectus was the same species as Adelges tsugae, and were synonymized, although no direct morphological comparisons were made. Within the Pacific Northwest, where this insect was first

1. This document is EENY-709, one of a series of the Department of Entomology and Nematology, UF/IFAS Extension. Original publication date July 2018. Visit the EDIS website at http://edis.ifas.ufl.edu. This document is also available on the Featured Creatures website at http://entomology.ifas.ufl.edu/ creatures.

2. Jeremiah R. Foley, Virginia Polytechnic Institute and State University; Scott Salom, Virginia Polytechnic Institute and State University; and Carey Minteer, assistant professor, Department of Entomology and Nematology, UF/IFAS Indian River Research and Education Center; UF/IFAS Extension, Gainesville, FL 32611. 
described, and Asia, hemlock woolly adelgid is not a threat to hemlocks presumably due to host resistance and natural enemies.

Decades later, in Richmond, VA in 1951, hemlock woolly adelgid was documented on eastern hemlocks (Evans and Gregoire 1996; Souto and Luther 1996). The adelgid introduced into Richmond, VA was from Japan and not from the western coast of North America (Havill and Montgomery 2006; Havill and Foottit 2007; Foottit and Maw 2009).

Eighteen years later, this introduced adelgid was reported to have spread to Pennsylvania (Figure 2) and by 1980 was causing significant mortality to eastern hemlocks (McClure 1989; McClure and Cheah 1999). Hemlock woolly adelgid continues to spread throughout the east coast and is now present in over 20 states and Nova Scotia.

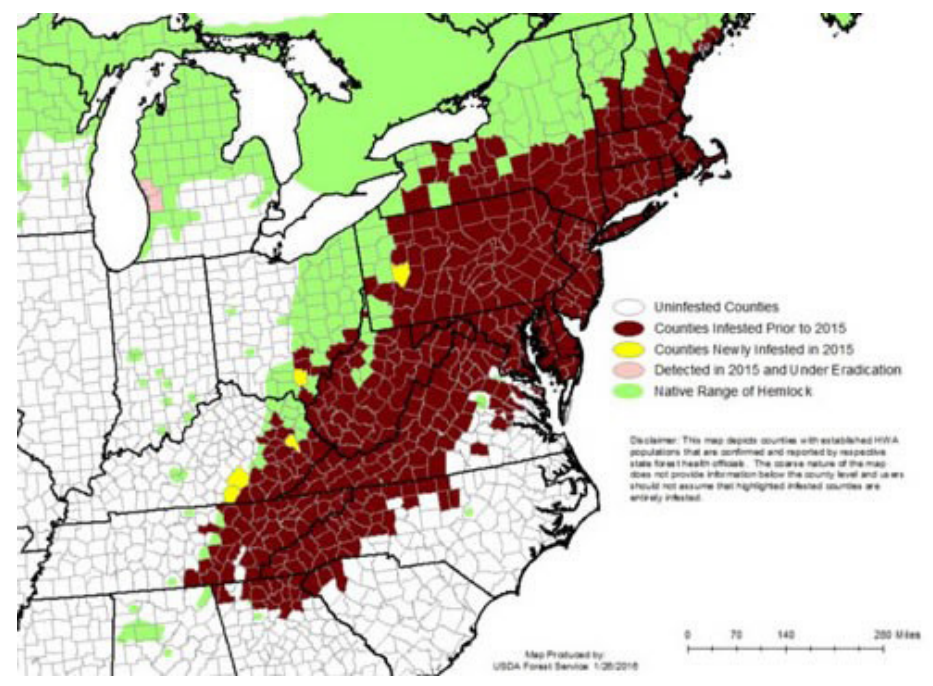

Figure 2. Historic range of hemlocks (Tsuga canadensis) in the eastern United States outlined in green and the distribution of hemlock woolly adelgid, Adelges tsugae, (brown) in 2015.

Credits: USDA Forest Service 2015

Birds are likely one of the primary local and long-distance dispersal agents of the hemlock woolly adelgid in eastern North America, the other leading agents being wind, deer, and humans. Birds inadvertently carry hemlock woolly adelgid eggs, first instar crawlers, and adults that attach to them while they feed in infested hemlocks. Studies have shown that during their spring migration, birds moving northward through the Southeastern and Mid-Atlantic states from Neotropical rainforests of Central and South America, most frequently acquire hemlock woolly adelgid from infested hemlock branches, or on the ground at the base of hemlocks, during peak crawler emergence in May. This coincides with the peak migration period of many of the Neotropical bird species. Since adelgids have been found on birds several kilometers from the nearest hemlocks, it is hypothesized that birds play an important but unintended role in the spread of hemlock woolly adelgid.

Common bird species passing through Florida and other Gulf states during the spring migration that may later stop over or nest in hemlock forests farther north, include the following, some of which have been documented carrying hemlock woolly adelgid: broad-winged hawk (Buteo platypterus), Acadian flycatcher (Empidonax virescens), red-eyed vireo (Vireo olivaceus), blue-headed vireo (Vireo solitarius), gray catbird (Dumetella carolinensis), American robin (Turdus migratorius), wood thrush (Hylocichla mustelina), ovenbird (Seiurus aurocapilla), northern parula (Setophaga americana), worm-eating warbler (Helmitheros vermivorum), blue-winged warbler (Vermivora cyanoptera), black-and-white warbler (Mniotilta varia), Tennessee warbler (Oreothlypis peregrina), magnolia warbler (Setophaga magnolia), Cape May warbler (Setophaga tigrina), bay-breasted warbler (Setophaga castanea), blackthroated green warbler (Setophaga virens), black-throated blue warbler (Setophaga caerulescens), yellow-rumped warlber (Setophaga coronata), Blackburnian warbler (Setophaga fusca), American redstart (Setophaga ruticilla), Canada warbler (Cardellina canadensis), scarlet tanager (Piranga olivacea) (McCulre 1990; Russo and Cheah 2016).

\section{Description}

\section{Eggs}

The eggs are laid within a woolly mass that is often referred to as an ovisac (Figure 3 ) and are approximately $0.36 \mathrm{~mm}$ in length, $0.23 \mathrm{~mm}$ in width, smooth, and oval. Eggs are slightly brown when laid and turn darker brown as they age (McClure 1989).

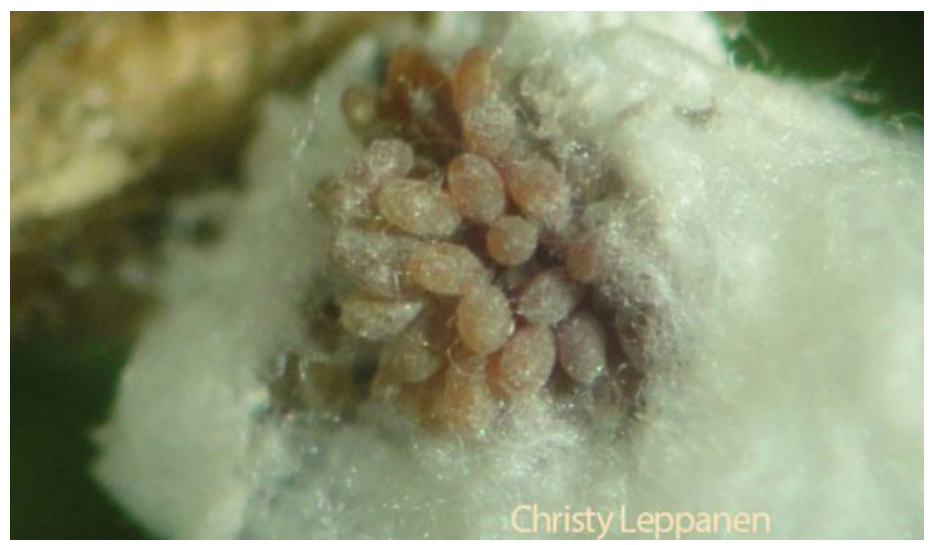

Figure 3. Hemlock woolly adelgid, Adelges tsugae, egg cluster. Credits: Christy Leppanen, University of Tennessee 


\section{Nymphs}

Four stages of nymphs (instars) are present. Determining nymphal stages can be difficult because as the adelgid molts, they remain with the wool. In practice, the most direct way to determine nymphal stage is to count the number of cast skins. The first instars (crawlers) are about $0.44 \mathrm{~mm}$ long (Figure 4) (McClure 1989). There are three subsequent instars that measure $0.57,0.67$, and $0.74 \mathrm{~mm}$ in length, respectively (McClure 1989).

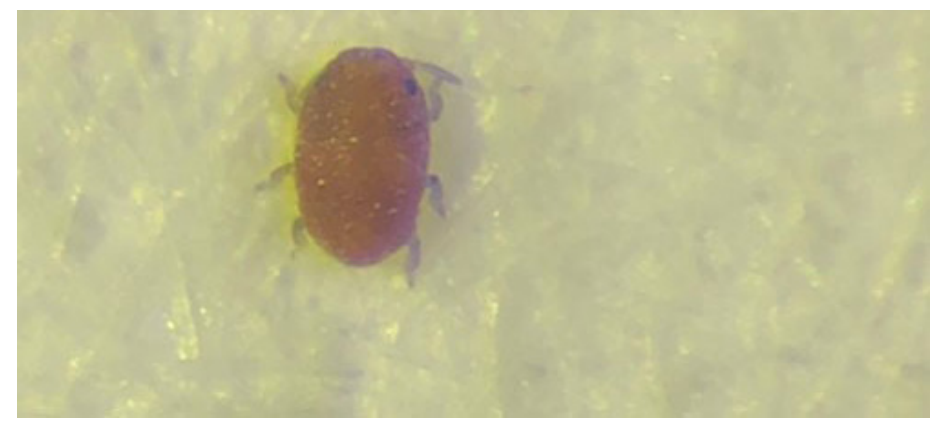

Figure 4. Hemlock woolly adelgid, Adelges tsugae, crawler (1st instar spring generation).

Credits: Jeremiah R. Foley, Virginia Polytechnic Institute and State University

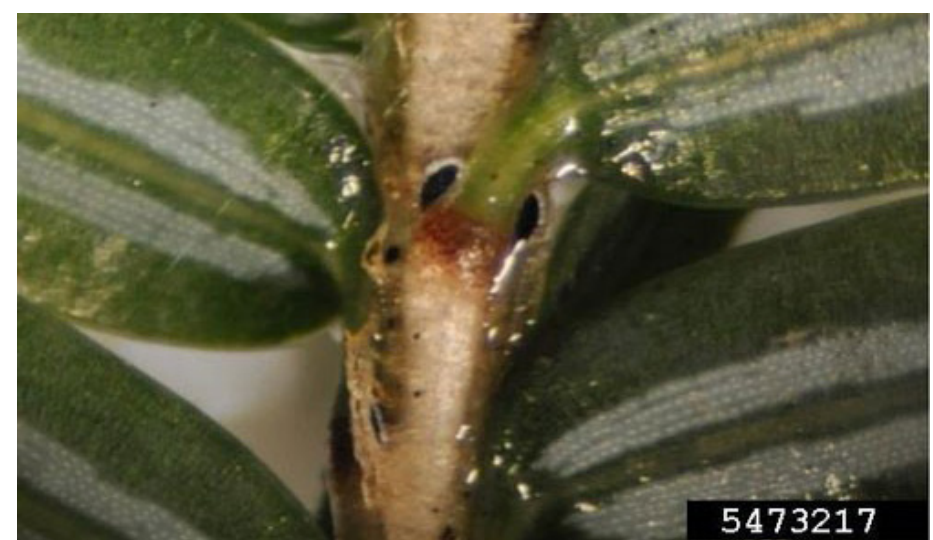

Figure 5. Aestivating hemlock woolly adelgid, Adelges tsugae, nymph (1st instar overwintering generation).

Credits: Ashley Lamb Galloway, Virginia Polytechnic Institute and State University

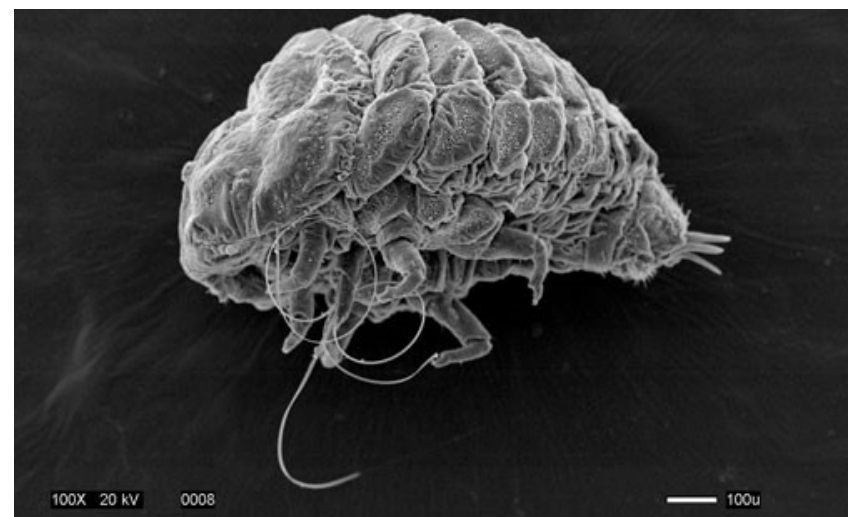

Figure 6. Scanning electron microscope (SEM) of an adult hemlock woolly adelgid, Adelges tsugae.

Credits: Kelly Oten, North Carolina Department of Agriculture and Consumer Services

\section{Life History}

Adelges tsugae (Hemiptera: Adelgidae) has a complex multigenerational life history with distinct morphological forms that have primary to secondary hosts (McClure 1989). During early summer, the overwintering generation eggs hatch (Figures 3 and 4) and settle at the base of a hemlock needle, and immediately enter aestivation (summer dormancy) as 1st instar nymphs (Figure 5). This generation of the adelgid known as sistens are completely sessile and will remain where they inserted their proboscis for the remainder of their life. During October in the US, the aestivating overwintering nymphs break dormancy and begin developing through four instars. During development, they produce a noticeable waxy woolly mass above their bodies, known as flocculence (Figures 1 and 3).

Development continues through winter, and by late winter through early spring, the nymphs develop into adults and begin laying eggs within the woolly mass. Development from egg to adult, for the spring generation, is much faster than in the overwintering generation. In Asia, a proportion of the adults develop into the winged sexupare and fly from their secondary host, hemlock, and migrate to their primary host, spruce, to complete sexual development. However, because their primary host, tigertail spruce, ( $P i$ cea torano (K. Koch) Koehne) is not present in the eastern United States or the Pacific Northwest, this is effectively a dead-end and all winged individuals die without completing their sexual generation. Non-winged adults remain on hemlock and begin laying eggs that are to become the overwintering generation. These eggs hatch, settle at the base of a needle, and enter aestivation; thereby completing its life cycle (McClure 1989; Gray and Salom 1995).

\section{The hemlock woolly adelgid, like all plant-feeding} hemipterans, extract stored plant nutrients by inserting their piercing-sucking mouthparts into the leafy cushion of specific plant cells. This results in significant damage to eastern hemlocks through the loss of needles and mortality of buds and branch tips that are responsible for regeneration. Once feeding has begun, it causes localized changes in specific plant tissues that favor hemlock woolly adelgid's survival and reproduction (Young and Shields 1995). There are two hypotheses that explain why eastern hemlocks are so dramatically impacted by the hemlock woolly adelgid. The first is their hypersensitive defensive response to feeding sites (Radville and Chaves 2011) causing infected needles to have higher elevated levels of $\mathrm{H}_{2} \mathrm{O}_{2}$ (hydrogen peroxide) at the site of herbivore feeding and the second is their lack of natural enemies as suggested through terpenoid analysis among the extant species of Tsuga. 
Eastern hemlock, relative to other Tsuga species worldwide, has fewer defensive compounds against piercing-sucking insects than against with biting-chewing insects (Lagalante and Montgomery 2003, Lagalante and Montgomery 2007).

\section{Management}

\section{Chemical Control}

There is a wide range of systemic insecticides used today (Cowles and Cheah 2002, Silcox 2002). These insecticides have been proven to control hemlock woolly adelgid populations effectively when applied as stem injections, soil drenching, foliar sprays, or soil injections (Steward and Braness 1998). However, depending on the size and scale of the area that needs to be treated (an individual tree or an entire forest), chemical control may not be feasible due to cost and accessibility. Whenever applying pesticides, instructions on the label should be followed to avoid non-target effects.

\section{Silvicultural Control}

Silvicultural options are available, which when properly executed, can mitigate the impact and spread of hemlock woolly adelgid in both forest and urban settings. More recently, it has been suggested that opening the canopy and allowing direct sunlight to reach the trees for long periods of the day could contribute to mortality of the hemlock woolly adelgid during the summer months (Whittier and Mayfield 2017). When weighing the various silvicultural management tactics, there must be a clear understanding of the specific goals for that given area which include but are not limited to: 1) wildlife habitat, 2) water quality control, 3) timber revenue, 4) aesthetics, 5) public safety, 6) future successional dynamic, or 7) a combination of all these goals. Once clear goals are set, there exists a spectrum of management options that ranges from do nothing to high intensity cutting. If the decision is made to cut hemlocks, Best Management Practices (BMPs) should be used as outlined by Kittredge and Parker (1989) to preserve soil and water quality.

\section{Gene Conservation/Host Resistance}

The international tree breeding and conservation program at North Carolina State University and other state and federal government agencies (USDA Forest Service) have collected hundreds of hemlock seeds from over 60 distinct populations of mother trees. The goal of this interagency program is to capture a strain of hemlock that is resistant to hemlock woolly adelgid infestations that can be used to repopulate hemlocks at a large geographic scale in areas that are most impacted by hemlock woolly adelgid.

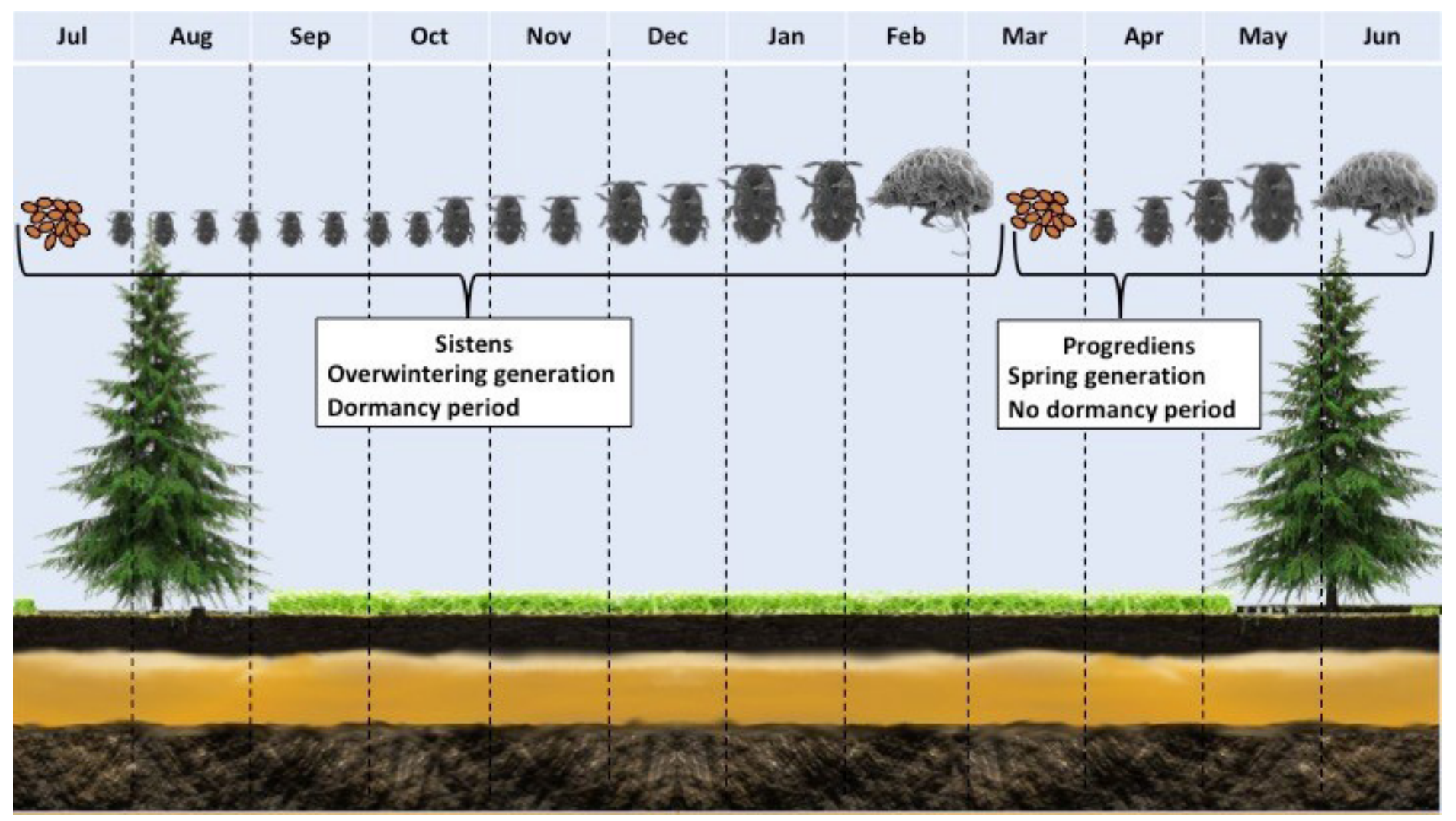

Figure 7. Hemlock woolly adelgid, Adelges tsugae, annual life cycle on hemlock in North America. 


\section{Integrated Pest Management}

Integrated pest management (IPM) strategies have had moderate success in long-term control of hemlock woolly adelgid populations in both forest and urban settings by combining chemical control, classical biological control, host plant resistance, and proper silvicultural practices. It is not likely that any one of these control methods would be effective on its own. Biological control has attracted the most interest and funding, and is thought to be the most promising solution to long-term control of hemlock woolly adelgid (Onken and Reardon 2011; Sumpter and McAvoy 2018).

\section{Natural Enemies}

There are no known parasitoids for the entire genus Adelges; however, there are a handful of coevolved and newly adapted predators in the native and introduced ranges of hemlock woolly adelgid, respectively, that are used as biological control agents (Zilahi-Balogh and Kok 2002, Cheah and Montgomery 2004, Zilahi-Balogh and Broeckling 2005, Vieira and McAvoy 2011). Since the hemlock woolly adelgid is native to both western North America and Asia, natural enemy surveys were conducted to evaluate the degree of specialization of existing predators to hemlock woolly adelgid with intentions of reestablishing these predators in eastern North America as biological control agents. Below are limited details on various predators thought to be the most important in terms of their impact on hemlock woolly adelgid.

\section{SASAJISCYMNUS TSUGAE}

The first foreign exploration of hemlock woolly adelgid predators was in Japan in 1992. During this exploration, a beetle (Insecta: Coccinellidae) that would later be named Sasajiscymnus tsugae, was discovered and later released in the eastern United States in 1995 (Sasaji and McClure 1997). Since their initial release, over two million have been reared and released at over 400 sites from South Carolina to Maine (Onken and Reardon 2011; Havill and Vieira 2014). Sasajiscymnus tsugae lacks a reproductive diapause mechanism and is also multivoltine (produces multiple generations per year). Sasajiscymnus tsugae generations overlap with both spring and overwintering adelgid generations (McClure 1987). Recoveries of this beetle have been lower than expected.

\section{LARICOBIUS NIGRINUS}

The entire genus of Laricobius (Insecta: Derodontidae) is host specific to various species of adelgids throughout the world. Laricobius nigrinus (Fender), is a small $(2-3 \mathrm{~mm}$ ) black beetle from the western temperate rainforests of the US and Canada, that has been released in eastern North America since 2003, after host specificity testing (Fender 1945; Zilahi-Balogh and Humble 2006). Since then, and until the beginning of 2018, Laricobius nigrinus was the focal point of mass rearing efforts made by Virginia Tech.

The eggs, nymphs, and adults of hemlock woolly adelgid are consumed by both the larvae and adults of Laricobius nigrinus. In addition, the life cycle for both predator and prey are highly synchronized (Zilahi-Balogh and Salom 2003). As populations continue to increase and spread, the degree at which Laricobius nigrinus is affecting the populations of hemlock woolly adelgid is becoming more apparent. While the long-term effects of Laricobius nigrinus adults and larva on the hemlock woolly adelgid in a field setting are currently being evaluated, preliminary results suggest that there is an impact on the overwintering generation and their ovisacs.

\section{LARICOBIUS RUBIDUS}

Laricobius rubidus (LeConte) is the only native Laricobius species present in eastern North America. The primary and preferred host for this predatory beetle is the pine bark adelgid (Pineus strobi Hartig), whose host is white pine (Pinus strobus L.). However, Laricobius rubidus has also been occasionally observed on balsam woolly adelgids (Adelges piceae Ratz) (Lawrence and Hlavac 1979) and on hemlock woolly adelgid, thus acting as a secondary host. Zilahi-Balogh and Broeckling (2005) demonstrated that while Laricobius rubidus can complete development on hemlock woolly adelgid, it prefers to oviposit on its primary host, pine bark adelgid. The establishment of Laricobius rubidus on hemlock woolly adelgid populations has likely contributed to the successful establishment of Laricobius nigrinus (and subsequent hybrids) since these sibling species can mate and produce viable offspring (Fischer and Havill 2015).

\section{LARICOBIUS OSAKENSIS}

Laricobius osakensis (Montgomery and Shiyake), is a small $(2-3 \mathrm{~mm}$ ), sexually dimorphic (males are black and females are reddish), host-specific predatory beetle of adelgids. This species was imported for release from Osaka, Japan for the control of hemlock woolly adelgid and was thought to have coevolved with the strain of adelgid introduced into eastern North America. Laboratory host range, performance, and phenology studies have shown this species to be superior to Laricobius nigrinus. Laricobius osakensis is now the main focus of mass rearing efforts made by Virginia Tech and is still being reared in concert with Laricobius nigrinus by 
other universities and local government agencies. Further studies are looking into how this insect performs in the field in relation to its impact, distribution, and phenology.

\section{LEUCOPIS SPP. (SILVER FLIES)}

The predatory silver flies Leucopis argenticollis (Zetterstedt) and Leucopis piniperda (Malloch) (Diptera: Chamaemyiidae), are native to both western and eastern North America. Based on morphological comparisons, these species are considered to be the same (Havill and Gaimari 2018). However, there is pronounced difference not only in the host preference between these two strains but also genetically. In western North America, these flies are generally found on adelgids on western hemlock and in eastern North America they are generally found on pine bark adelgids on white pine. There has been no reporting of these species on adelgids on eastern hemlocks.

Since 2015, considerable work was done to release the west coast strain of Leucopis spp. into eastern North America (Motley and Havill 2017). While adult predatory Laricobius beetles and their larvae are present during winter and spring, respectively, adult silver flies and their larvae are present in late spring and throughout summer, when aestivating hemlock woolly adelgid nymphs are present. Used together, the temporal separation between the predatory beetles and silver flies will allow for year-round predation and will likely have a higher impact on hemlock woolly adelgid populations.

\section{Selected References}

Annand P. 1924. "A new species of Adelges (Hemiptera: Phylloxeridae)." Pan-Pacific Entomologist 12: 79-82.

Carter CI. 1971. "Conifer woolly aphids (Adelgidae) in Britain." Bulletin for Communication, London 42.

Cheah C, Montgomery M, Salom S, Parker B, Costa S, Skinnner M. 2004. Biological control of hemlock woolly adelgid. United States Department of Agriculture, Forest Service, Forest Health Technology Enterprise Team, Morgantown 22.

Chrystal RN, Story F. 1922. “The Douglas fir Chermes: (Chermes cooleyi)." Forest Commission, Bulletin no. 4.

Cowles R, Cheah C. 2002. "Systemic control of hemlock woolly adelgid, 1999." Arthropod Management Tests 27.

Evans R, Johnson E, Shreiner J, Cleavitt N, Fahey T, Sciascia J, Pehek E. 1996. Potential impacts of hemlock woolly adelgid (Adelges tsugae) on eastern hemlock (Tsuga canadensis) ecosystems. In Salom SM, Tigner TC, Reardon RC. (eds). Proceedings of the first hemlock woolly adelgid review. Charlottesville, VA, USA. pp. 42-57.

Evans AM, Gregoire TG. 2007. "A geographical variable model of hemlock woolly adelgid spread." Biological Invasions 9: 369-382.

Fender K. 1945. "A new Laricobius from Oregon.” Pan-Pac. Entomology 21: 152.

Fischer MJ, Havill NP, Brewster CC, Davis GA, Salom SM, Kok LT. 2015. "Field assessment of hybridization between Laricobius nigrinus and L. rubidus, predators of Adelgidae." Biological Control 82: 1-6.

Foottit RG, Maw HEL, Havill NP, Ahren RG, Montgomery ME. 2009. "DNA barcodes to identify species and explore diversity in the Adelgidae (Insecta: Hemiptera: Aphidoidea)." Molecular Ecology Resources 9s1: 188-195.

Gray DR, and Salom SM. 1996. Biology of hemlock woolly adelgid in the southern Appalachians. In Salom SM, Tigner TC, Reardon RC. (eds). Proceedings of the First Hemlock Woolly Adelgid Review. USDA Forest Service, Charlottesville, VA, USA. pp. 26-35.

Havill NP, Montgomery M, Guoyue Y, Shiyake S, Caccone A. 2006. "Mitochondrial DNA from hemlock woolly adelgid (Hemiptera: Adelgidae) suggests cryptic speciation and pinpoints the source of the introduction to eastern North America." Annals of the Entomological Society of America 99: 195-203.

Havill NP, Foottit RG. 2007. "Biology and evolution of Adelgidae." Annual Review of Entomology 52: 325-349.

Havill NP, Vieira LC, Salom SM. 2014. Biology and control of hemlock woolly adelgid, United States Department of Agriculture, Forest Health Technology Enterprise Team. FHTET-2014-05.

Havill NP, Gaimari SD, Caccone A. 2018. "Cryptic east-west divergence and molecular diagnostics for two species of silver flies (Diptera: Chamaemyiidae: Leucopis) from North America being evaluated for biological control of hemlock woolly adelgid." Biological Control 121: 23-29.

Heie OE. 1987. Paleontology and phylogeny. Aphids: Their Biology, Natural Enemies and Control Vol 2: 367-391. Elsevier, Amsterdam. 
Kittredge D, Parker M. 1989. Massachusetts Best Management Practices: Timber Harvesting Water Quality Handbook. Cooperative Extension, University of Massachusetts and Massachusetts Department of Environmental Management. $46 \mathrm{p}$.

Lagalante AF, Montgomery ME. 2003. "Analysis of terpenoids from hemlock (Tsuga) species by solid-phase microextraction/gas chromatography/ion-trap mass spectrometry." Journal of Agricultural and Food Chemistry 51: 2115-2120.

Lagalante AF, Montgomery ME, Calvosa FC, Mirzabeigi MN. 2007. "Characterization of terpenoid volatiles from cultivars of eastern hemlock (Tsuga canadensis)." Journal of Agricultural and Food Chemistry 55: 10850-10856.

Lawrence JF, Hlavac T. 1979. "Review of the Derodontidae (Coleoptera: Polyphaga) with new species from North America and Chile." The Coleopterists' Bulletin 33: 369-414.

McClure MS. 1989. "Evidence of a polymorphic life cycle in the hemlock woolly adelgid, Adelges tsugae (Homoptera: Adelgidae)." Annals of the Entomological Society of America 82: $50-54$.

McClure MS. 1990. "Role of wind, birds, deer, and humans in the dispersal of hemlock woolly adelgid (Homoptera: Adelgidae)." Environmental Entomology 19: 36-43.

McClure MS, Cheah C. 1999. "Reshaping the ecology of invading populations of hemlock woolly adelgid, Adelges tsugae (Homoptera: Adelgidae), in eastern North America." Biological Invasions 1: 247-254.

McClure MS. 2001. Biological control of hemlock woolly adelgid in the eastern United States. Forest Health Technology Enterprise Team 2000-08. USDA Forest Service, Morgantown, W.Va.

Motley K, Havill NP, Arsenault-Benoit AL, Mayfield AE. 2017. "Feeding by Leucopis argenticollis and Leucopis piniperda (Diptera: Chamaemyiidae) from the western USA on Adelges tsugae (Hemiptera: Adelgidae) in the eastern USA." Bulletin of Entomological Research 107: 699-704.

Onken BP, Reardon RC (eds). 2011. Implementation and Status of Biological Control of the Hemlock Woolly Adelgid. Forest Health Technology Enterprise Team. 230 pp.

Radvill L, Chaves A, Preisser EL. 2011. "Variation in plant defense against invasive herbivores: Evidence for a hypersensitive response in eastern hemlocks (Tsuga canadensis)." Journal of Chemical Ecology 37: 592-597.

Russo NJ, Cheah C, Tingley MW. 2016. "Experimental evidence for branch-to-bird transfer as a mechanism for avian dispersal of the hemlock woolly adelgid (Hempitera: Adelgida)." Environmental Entomology 45(5): 1107-1114.

Sasaji H, McClure MS. 1997. "Description and distribution of Pseudoscymnus tsugae sp. nov. (Coleoptera: Coccinellidae), an important predator of hemlock woolly adelgid in Japan." Annals of the Entomological Society of America 90: 563-568.

Silcox CA. 2002. Using imidacloprid to control hemlock woolly adelgid. Proceedings of the Hemlock Woolly Adelgid in the Eastern United States Symposium, East Brunswick, NJ. pp. 280-287.

Souto D, Luther T, Chianese B. 1996. Past and current status of HWA in eastern and Carolina hemlock stands. In Salom SM, Tigner TC, Reardon RC. (eds). Proceedings of the First Hemlock Woolly Adelgid Review. USDA Forest Service, Charlottesville, VA, USA. pp. 9-15.

Steward VB, Braness G, Gill S. 1998. "Ornamental pest management using imidacloprid applied with the Kioritz [R] soil injector." Journal of Arboriculture 24: 344-346.

Sumpter KL, McAvoy TJ, Brewster CC, Mayfield AE, Salom SM. 2018. "Assessing an integrated biological and chemical control strategy for managing hemlock woolly adelgid in southern Appalachian forests." Forest Ecology and Management 411: 12-19.

Vieira LC, McAvoy TJ, Chantos J, Lamb AB, Salom SM, Kok LT. 2011. "Host range of Laricobius osakensis (Coleoptera: Derodontidae), a new biological control agent of hemlock woolly adelgid (Hemiptera: Adelgidae)." Environmental Entomology 40: 324-332.

Young RF, Kathleen SS, Graeme PB. 1995. "Hemlock woolly adelgid (Homoptera: Adelgidae): Stylet bundle insertion and feeding sites." Annals of the Entomological Society of America 88: 827-835.

Whittier W, Mayfield AE, Jetton R. 2017. Silvicultural and integrated pest management strategies for restoring eastern hemlock to degraded southern Appalachian mountain ecosystems. In Sniezko RA, Man G, Hipkins V, Woeste K, Gwaze D, Kliejunas JT, McTeague BA (technical coordinators). Gene conservation of tree species-banking on the 
future. Proceedings of a workshop. General Technical Report PNW-GTR-963. Portland, OR: US Department of Agriculture, Forest Service, Pacific Northwest Research Station. pp. 206.

Zilahi-Balogh GM, Kok LT, Salom SM. 2002. "Host specificity of Laricobius nigrinus Fender (Coleoptera: Derodontidae), a potential biological control agent of the hemlock woolly adelgid, Adelges tsugae Annand (Homoptera: Adelgidae)." Biological Control 24: 192-198.

Zilahi-Balogh GM, Salom SM, Kok LT. 2003. "Development and reproductive biology of Laricobius nigrinus, a potential biological control agent of Adelges tsugae." BioControl 48:

293-306.

Zilahi-Balogh GMG, Broeckling CD, Kok LT, Salom SM. 2005. "Comparison between a native and exotic adelgid as hosts for Laricobius rubidus (Coleoptera: Derodontidae)." Biocontrol Science and Technology 15: 165-171.

Zilahi-Balogh GMG, Humble LM, Kok LT, Salom SM.

2006. "Morphology of Laricobius nigrinus (Coleoptera: Derodontidae), a predator of the hemlock woolly adelgid." The Canadian Entomologist 138: 595-601. 